ELORE (ISSN 1456-3010), vol. 19 - 2/2012.

Julkaisija: Suomen Kansantietouden Tutkijain Seura ry.

[http://www.elore.fi/arkisto/2_12/vakimo.pdf]

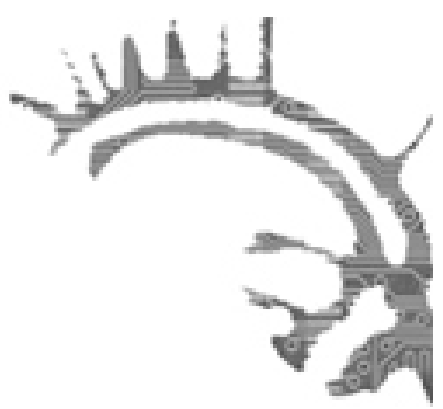

\title{
EMINENTIA-LIITE
}

\section{EMINENTIA-LUENTOJEN TAUSTAKSI}

\author{
Sinikka Vakimo
}

Suomen Kansantietouden Tutkijain Seuran esimiehen avaussanat Eminentialuentoihin 15.5.2012 Tieteiden talossa Helsingissä.

Suomen Kansantietouden Tutkijain Seura (SKTS) täytti viime keväänä 75 vuotta. Seuraa oli vuonna 1937 Helsingissä perustamassa joukko suomalaisia kansantietouden tutkijoita, joista ensimmäiseen johtokuntaan valittiin seuran esimieheksi professori Väinö Salminen, varaesimiehiksi professorit V. J. Mansikka ja Uno Harva ja sihteeriksi dosentti Aukusti Rantasalo. Muita johtokunnan jäseniä olivat professorit Albert Hämäläinen, Artturi Kannisto ja Viljo Tarkiainen. Koolla oli siis hyvin vaikutusvaltainen ja monitieteisesti kansanrunouteen, kansatieteeseen, kirjallisuuteen ja kielentutkimukseen suuntautunut miesjoukko.

Vastaperustetun seuran tarkoituksena "oli olla yhdyssiteenä Suomen kansantietouden tutkijain välillä, edistää mainitun tieteen tutkimista ja tehdä sen tuloksia tunnetuksi ulkomailla; pitää kokouksia ja julkaista alaansa kuuluvia tutkimuksia ja aineskokoelmia", kuten ilmoituksessa yhdistysrekisteriin 12.4.1937 todetaan.

Joitakin näistä tavoitteista toteutui seuran senaikaisessa toiminnassa; seura julkaisi muun muassa muutamia numeroita omassa Mitteilungen-sarjassaan. Aika nopeasti aktiivisuus kuitenkin hiipui, mihin oli varmaankin monia syitä, kuten sota-aika jälkiseurauksineen. Lisäksi on mahdollista, ettei tällaiseen suomalaiskansallisen identiteetin rakentamisprojektiin kytkeytyneeseen ja laajasti niin sanottujen kansallisten tieteiden kehyksestä ponnistaneeseen seuratoimintaan ollut enää tarvetta. Seuralla oli jo tuol- 
loin paljon vakiintuneita, pitkälti samoihin päämääriin suuntaavia kilpailijoita, joista tärkeimpiä olivat tietenkin Suomalaisen Kirjallisuuden Seura ja Kalevalaseura.

Seuran toimintaa heräteltiin henkiin näkyvämmin vasta 1970-luvun alussa Helsingin yliopiston kansanrunoustieteen laitoksella, jolloin pidettiin seuran kokous joulukuun 1. päivänä vuonna 1971. Seuran silloinen I varasesimies, akateemikko Kustaa Vilkuna toimi kokouksen puheenjohtajana ja lisensiaatti Anna-Leena Kuusi sihteerinä. Kokouspöytäkirjassa todetaan, että kuluneilta vuosilta ei ollut vuosikertomuksia eikä tilinpäätöksiä, ja että seuran paperit olivat vuodesta 1950 olleet SKS:n käsikirjoitusarkistossa säilytettävänä. Seura oli kuitenkin ollut tukemassa Helsingin yliopiston kansanrunoustieteen laitoksen julkaisutoimintaa ja akateemista matkailua sekä jakanut joitakin stipendejä. Yksi tällainen oli $10 \mathrm{mk}$ matkakulukorvaus kuudelle laitoksen lisensiaattiseminaarin jäsenelle, jotka osallistuivat kokouspöytäkirjan mukaan Turun yliopiston kansanrunoustieteen laitoksen järjestämään seminaarikokoukseen. Matkastipendin saaneet olivat Jöns Carlson, Philip Donner, Henni Ilomäki, Anna-Leena Kuusi, Kari Laukkanen ja Helinä Rautavaara.

Seuran jäsenmäärä oli supistunut 18 jäseneen, mistä syystä seura päätti kutsua mukaan 14 uutta jäsentä. Nyt seuran uudeksi esimieheksi valittiin professori Matti Kuusi ja varaesimiehiksi dosentit Leea Virtanen ja Pentti Leino sekä sihteeriksi lisensiaatti Annikki Kaivola. Muina johtokunnan jäseninä toimivat dosentti Matti Hako, lisensiaatti Anna-Leena Kuusi ja arkistonjohtaja Urpo Vento. Jälleen koossa oli arvovaltainen tutkijajoukko, joka oli edelliseen johtoryhmään verrattuna hieman naisistunut ja myös tiiviimmin folkloristiikkaan rajautunut, mikä heijastelee paitsi koko Suomen, myös akateemisen ja humanististen tieteiden kentän muutosta seuran perustamisajoista. Seura eriytyikin tässä vaiheessa väljän monitieteisestä kansallisten tieteiden seurasta folkloristien omaksi tiedeseuraksi.

Toiminta jäi kuitenkin tuolloinkin varsin vähäiseksi, ja näin kävi myös 1980-luvulla, jolloin professori Leea Virtasen johtamaa ja lisensiaatti Seppo Knuuttilan sihteerinä peesaavaa seuraa pidettiin ilmeisesti hengissä lähinnä eräänlaisen kansanrunoustieteen laitoksen julkaisu- ja matkatukiorganisaationa. Myös seuran jäsenrekisteriä päivitettiin ajoittain. Seuran toimijat pitivät kuitenkin vuosien aikana huolta siitä, että seura pysyi Tieteellisten Seurojen Valtuuskunnan jäsenenä, mikä on avittanut suuresti seuran tulevia toimijoita.

Seuran kolmas tuleminen koettiin 1990-luvun alkupuolella, kun joensuulaiset perinteentutkijat professori Anna-Leena Siikalan johdolla innostuivat seuran henkiin herättelystä. Silloisen seuran esimiehen, professori Leea Virtasen johtama seuran kokous kokoontui 2. marraskuuta 1992 päättämään seuran toiminnan jatkamisesta. Seuralle valittiin uusi johtoryhmä ja esimieheksi Seppo Knuuttila. Varaesimiehiksi valittiin Satu Apo ja Anna-Leena Siikala ja sihteeriksi Jyrki Pöysä. Muiksi johtokunnan jäseniksi valittiin Pekka Hakamies, Kaija Heikkinen ja Annikki Kaivola-Bregenhøj. Kyseisten henkilöiden sen aikaisia titteleitä ei Leea Virtasen laatimassa niukassa kokousmuistiossa mainita, mutta on helppo havaita, että uudeksi johtokunnaksi onnistuttiin saamaan arvovaltainen perinteentutkimuksen ja folkloristiikan asiantuntijajoukko.

Seuran toiminta on kantanut näistä seuran kolmannen tulemisen vuosista lähtien tähän päivään asti. Seuran sääntöjä muutettiin heti alkajaisiksi ja seuran kotipaikaksi 
vaihdettiin Joensuu, joskin seura on aina pyrkinyt toimimaan valtakunnallisesti. Mutta vaikka sääntöjä hieman muutettiin, on toiminnan ydin pysynyt jo vuonna 1937 hahmotellussa linjassa: "Seura on toiminut yhdyssiteenä alan tutkijoiden välillä, on edistänyt alan tutkimista, pitänyt kokouksia ja seminaareja ja julkaissut alaansa kuuluvia tutkimuksia." Näistä tärkeimpänä mainittakoon pääosin seuran sihteerin, Jyrki Pöysän ennakkoluulottoman ponnistelun tuloksena synnytetty Elektroloristi-lehti, joka muutti nimensä nykyiseksi Eloreksi vuoden 1998 alussa. Se alkoi ilmestyä vuonna 1994 aikaansa edellä olevana avoimen saatavuuden verkkolehtenä ja saavutti tieteellisen lehden tunnuskriteerit vuonna 2003, jolloin lehti siirtyi noudattamaan referee-käytäntöä artikkeleiden arvioinnissa. Lehden jatkona seuralle luotiin oma julkaisusarja, Kultaneito, vuonna 1996, mistä alkaen sarjassa on ilmestynyt kahdeksan numeroa, viimeisimpänä Vaeltavat metodit (2010). Kuluvana syksynä sarjassa ilmestyy ensimmäinen perinteentutkimuksen alan väitöskirja. Säännöllisistä seminaareista on Kevätkoulu-tapahtumaa järjestetty vuodesta 2006 alkaen.

Tässä yhteydessä ei ole syytä eritellä seuran toimintamuotoja tämän tarkemmin (ks. seuran nettisivut http://www.kansantietoudentutkijat.fi). Sen sijaan korostan sitä, että seuralaisten toiminnan motiivina on aina ollut kiinnostus ja innostus tieteenalan - määritellään se sitten vallalla olevien tutkimusvirtausten mukaisesti kansantietoudeksi, kansanrunoudentutkimukseksi, folkloristiikaksi, perinteentutkimukseksi tai väljemmin perinnetieteiksi tai peräti kulttuuritieteiksi - edistämiseen ja kehittämiseen. Tähän on pyritty paitsi julkaisuja tuottamalla ja keskustelemalla tekstien avulla, myös hankkiutumalla kasvokkaiskontaktiin toisten folkloristikollegojen ja muiden alojen tutkijoiden kanssa. Siis keskusteluun, ajatusten vaihtamiseen, ideointiin ja väittelyyn - ja joskus myös taivaanrannan maalailuun, maailman muuttamiseen ja kollektiiviseen ilonpitoonkin. Tämä yhdessä tekeminen ja ajatusten vapaa vaihtaminen on nähdäkseni tieteellisen seuran perusta siinä missä minkä tahansa muunkin seuran; se on perusta, jonka merkitys nykyajan julkaisutehokkuutta korostavassa akateemisessa maailmassa unohdetaan turhan herkästi.

Edellä esiin nostetut seuran toiminnan toistuvat käynnistämisyritykset voi nähdä julkaisuissa esitettyjen avausten lisäksi - ilmauksina tarpeesta saada kehittää tieteenalaa yhdessä keskustellen ja alan tutkijoille omaa identiteettiä rakentaen. Toki aloitteita yhteiselle keskustelulle on ajoittain tehty muuallakin kuin seuran parissa. Yksi tällainen keskustelun avausyritys tehtiin joulukuun 15. päivänä vuonna 1959, jolloin Hotelli Helsinkiin kokoontui sellaisia kansanperinteen tutkijoita kuin Martti Haavio, Matti Hako, Jouko Hautala, Lauri Honko, Matti Kuusi, Lauri Simonsuuri, Asko Vilkuna ja Leea Virtanen. Kokouksen tarkoituksena oli vakinaistaa käytäntö, jossa: "[...] kansanrunoudentutkijat voisivat silloin tällöin kokoontua viljelemään vapaata sanaa tieteensä yleisluonteisista ongelmista. Eräänlaiseksi pääteemaksi voitaisiin valita kysymys: mitkä ovat nykyhetken kansanrunoudentutkimuksen kysymyksenasettelut ja työmenetelmät?". Ilmeisesti tuolloin koettiin, etteivät SKS tai muut alan laitokset ja seurat tarjoa riittävän rajattua foorumia folkloristiselle metodikeskustelulle - ja tutkijain vapaamuotoiselle ajatusten vaihdolle.

Tässä kokouksessa, josta Leea Virtanen laati pöytäkirjan, käytiin vilkasta keskustelua. Aluksi kokouksessa mietittiin itse tieteellisen keskustelun laatua. Matti Kuusi näki nou- 
sukausina keskusteltavan erityisen paljon, millä hän viittasi vanhaan Krohnin ja Setälän väliseen metodiväittelyyn. Kuusen mukaan 1930-luvulla tieteellinen keskustelun taso oli romahtanut, mihin Kuusen mukaan oli kenties syynä "liian raa’at aseet", kuten pöytäkirja kertoo. Ilmeisesti Kuusi ei ollut tyytyväinen kokouksen ajankohdan keskusteluun, koska hänen mukaansa ennen käytiin herkemmin tutkimuksen olennaisten yksipuolisuuksien kimppuun, kun niitä havaittiin. Sen sijaan silloisen nykyajan, siis 1950-luvun lopun, keskustelussa varottiin Kuusen mielestä aloja, joilla toinen on liikkunut ja keskusteltiin näin enemmän rivien välistä; keskustelu oli muuttunut hienovaraisemmaksi. Kuusen havainto toisten tutkimien alojen "varomisesta" pitää varmastikin paikkansa, mutta sen voi nähdä kuvaavan hienotunteisuuden lisäksi myös tieteenalan moninaistumisen prosessia, joka oli ollut vahvasti käynnissä jo tuolloin. Siten kaikki alan tutkijat eivät keskittyneet kansanrunouden tutkimukseen, vaan uusia perinteenlajeja ja myös uudenlaisia tutkimussuuntia alettiin soveltaa, mikä samalla merkitsi myös keskustelun osittaista hajaantumista.

Pöytäkirjasta käy myös ilmi, että Martti Haavio oli nostanut esiin kansainvälisellä rintamalla tapahtuvan keskustelun tärkeyden vedoten jo Krohnin tähdentäneen ulkomaankielillä julkaisemisen merkittävyyttä. Lisäksi Haavio oli nostanut esiin folklorististen kysymystenasetteluiden muotoilun tärkeyden. Jouko Hautala taas oli huomauttanut vaikeuksista keskustella metodikysymyksistä, koska hänen mukaansa se mitä tutkimuksessa halutaan saada selville, määrää metodin, eikä Hautalan mukaan ole olemassa kuin yksi menetelmä, tieteellinen menetelmä apukeinoineen. Lauri Honko oli korostanut tutkimusaspektien moninaisuutta ja Lauri Simonsuuri toivonut tulevien kokoontumisten ottavan lähtökohdakseen maantieteellis-historiallisen metodin. Matti Hako oli vielä tuonut keskusteluun mukaan sosiologian ja kirjallisuustieteen mahdollisen annin kansanrunoudentutkimukselle.

Leea Virtasen pitämä kokouspöytäkirja päättyy hänen siihen myöhemmin lisäämäänsä loppukaneettiin, jossa mainitaan, että "Muistaakseni seuraavaa kokousta ei syystä tai toisesta tullut eikä pitämääni pöytäkirjaa koskaan luettu. LV” Todennäköisesti sihteerin loppulisäys oli ironinen kommentti käytyyn keskusteluun ja sen poukkoilemiseen laidasta laitaan. Keskusteludokumentti on kuitenkin kiinnostava nykyajan perspektiivistä, sillä siitä välittyy hyvin alan tutkimussuuntien murros yhden vallitsevan tutkimuslinjan hiipumisesta ja folkloristisen tutkimuskentän avautumisesta uusille näkökulmille ja eri tieteenalojen tuomille teoreettisille virikkeille.

Lisäksi Kuusen kommentti tieteellisen metodikeskustelun nousu- ja laskukausista ja niiden yhteydestä yhteiskunnallis-kulttuuriseen kontekstiin ja toisaalta näkemykset keskustelun suoruudesta tai varovaisuudesta saavat miettimään tämän hetken perinnetieteiden keskustelun tilaa. Myös Haavion esiin nostamat tieteenteon kansainväliset aspektit ovat nykyisen akateemisen maailman keskiössä, kuten myös vuoden 1959 kokouksessa ilmaan heitetyt metodiset problematisoinnit folkloristisesti hedelmällisistä kysymyksenasetteluista, metodeista ja vuorovaikutuksesta lähitieteiden kanssa.

Metodikeskustelu on tietenkin itsestään selvä minkä tahansa tieteenalan perusta nykyaikanakin; siis sen pohtiminen, miten ja minkälaisin tutkimusottein ja menetelmin perinnettä tulisi tutkia, määrittää ja tulkita. Toisaalta nykysukupolven tutkijat eivät enää voi edeltäjiensä tavoin pitäytyä pelkästään perinteentutkimuksen tai folkloristiikan 
sisäisessä keskustelussa, vaan tutkimukselta odotetaan yhä merkittävämpää avautumista ympäröivän yhteiskunnan suuntaan. Yhtenä alan haasteena onkin lisätä ymmärrystämme ja esittää vaihtoehtoja niistä kulttuurisista kysymyksistä, jotka tällä hetkellä koetaan yhteiskunnallisesti merkittäviksi.

Kukin tutkijasukupolvi määrittää tietenkin alansa ydinkysymyksiä omista, ajalle relevanteiksi nähdyistä suunnistaan, mutta parhaimmillaan kuitenkin aiempia tutkimustraditioita ymmärtäen ja niiden näkemyksistä oppien. Tämä ajatus oli myös toukokuussa pidetyn Suomen Kansantietouden Tutkijain 75-vuotisjuhlaseminaarin, Eminentia-luentojen lähtökohtana: avata uusia näkökulmia folkloreen ja sen tutkimiseen oppihistoriallisten tarkasteluiden perustalta. Seura pyysikin alalla huomattavan aseman saavuttaneita, eteviä asiantuntijoita - siis eminenssejä - pitämään puheenvuoron, jossa tarkastellaan reflektoiden folkloristiikan keskeisiä kysymyksiä oman tutkijankokemuksensa näkökulmasta. Pyyntöömme suhtauduttiin varsin suopeasti. Saimme näin toukokuussa kuulla neljä hienoa Eminentia-luentoa professoreilta Pekka Laaksonen, Satu Apo, Aili Nenola ja Seppo Knuuttila ja käydä keskustelua niiden virittämänä. Seminaarin päätössanat esitti professori Pekka Hakamies. Käsillä olevassa Elore-lehdessä julkaistaan tätä Eminentia-luentojen antia. Niiden siivittämänä voimme siis vastedeskin viljellä vapaata sanaa tieteemme yleisluonteisista ongelmista, keskustella tieteellisten ongelmien kimppuun sopivasti käyden, tarvittaessa rivien välissä hiipien tai vaikka sinne tänne poukkoillen - siis siten kuin vain kansantietoudentutkijat osaavat.

Filosofian tohtori Sinikka Vakimo on SKTS:n esimies ja hoitaa perinteentutkimuksen professuuria Itä-Suomen yliopistossa. 